\title{
Correction to: Impact of whole dairy matrix on musculoskeletal health and aging-current knowledge and research gaps
}

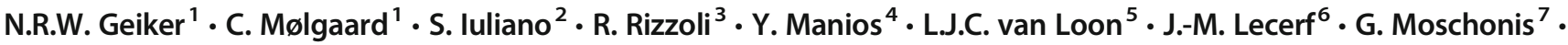 \\ J.-Y. Reginster ${ }^{8} \cdot$ I. Givens $^{9} \cdot$ A. Astrup ${ }^{1}$
}

Published online: 13 January 2020

(C) The Author(s) 2020

\section{Correction to: Osteoporosis International https://doi.org/10.1007/s00198-019-05229-7}

The article "Impact of whole dairy matrix on musculoskeletal health and aging-current knowledge and research gaps" written by N.R.W. Geiker, C. Mølgaard, S. Iuliano, R. Rizzoli,Y. Manios, L.J.C. van Loon, J.-M. Lecerf, G. Moschonis, J.-Y. Reginster, I. Givens, and A. Astrup was originally published electronically on 14 November 2019 without open access. With the author(s)' decision to opt for Open Choice, the copyright of the article changed on January 2020 to (C) The Author(s) 2019 and the article is forthwith distributed under the terms of a Creative Commons Attribution-NonCommercial 4.0 International License (https://creativecommons.org/licenses/bync/4.0/), which permits any non-commercial use, sharing, adaptation, distribution and reproduction in any medium or format, as long as you give appropriate credit to the original author(s) and the source, provide a link to the Creative Commons licence, and indicate if changes were made.

The online version of the original article can be found at https://oi.org/ 10.1007/s00198-019-05229-7

N.R.W. Geiker

geiker@nexs.ku.dk

1 Department of Nutrition, Exercise and Sports, Faculty of Science, University of Copenhagen, Rolighedsvej 26, DK-1958 Frederiksberg C, Denmark

2 Department of Endocrinology, University of Melbourne, Austin Health, Melbourne, Australia

3 Division of Bone Diseases, Geneva University Hospitals and Faculty of Medicine, Geneva, Switzerland

4 Department of Nutrition \& Dietetics, Harokopio University, Athens, Greece
Open Access This article is licensed under a Creative Commons Attribution-NonCommercial 4.0 International License, which permits any non-commercial use, sharing, adaptation, distribution and reproduction in any medium or format, as long as you give appropriate credit to the original author(s) and the source, provide a link to the Creative Commons licence, and indicate if changes were made. The images or other third party material in this article are included in the article's Creative Commons licence, unless indicated otherwise in a credit line to the material. If material is not included in the article's Creative Commons licence and your intended use is not permitted by statutory regulation or exceeds the permitted use, you will need to obtain permission directly from the copyright holder. To view a copy of this licence, visit http:// creativecommons.org/licenses/by-nc/4.0/.

Publisher's note Springer Nature remains neutral with regard to jurisdictional claims in published maps and institutional affiliations.

NUTRIM School of Nutrition and Translational Research in Metabolism, Department of Human Biology, Maastricht University, Medical Centre+, Maastricht, the Netherlands

6 Department of Nutrition and Physical Activity, Institut Pasteur de Lille, Lille, France

7 Department of Dietetics, Nutrition and Sport, La Trobe University, Melbourne, Australia

8 World Health Organization Collaborating Center for Public Health Aspects of Musculoskeletal Health and Aging, University of Liège, Liège, Belgium

9 Institute for Food, Nutrition and Health, University of Reading, Reading, UK 